\title{
'CAN SHE EXCUSE MY WRONGS?' THE EUROPEAN COURT OF JUSTICE AND INTERNATIONAL COURTS AND TRIBUNALS
}

\begin{abstract}
Bernhard Hofstötter*
Summary: The multiplication of international courts and tribunals in recent decades has paved the way for a judicialisation of international law and has therefore profoundly changed the landscape of international law. Whereas the existence of a panoply of dispute resolution avenues is a welcome development which may be conceptualised as part of an ongoing constitutionalisation of international law, it has concomitantly activated the problem of conflict between different judicial actors. Although doubtlessly designed as an international court sui generis, the ECJ forms part of this international dispute settlement architecture and has to compete with other international actors in the case of jurisdictional overlaps. The recent MOX plant saga is an illustration of these competing forces at play and underscores the self-perception of the ECJ as a constitutional court reluctant to pay deference to the pronouncements of other international judicial actors. Although fitting squarely with the Court's mandate issued by the framers of the EC Treaty in Article 292, this approach risks an undesirable fragmentation of international law as a whole, which could be avoided by reference to a number of conflict avoidance devices available to international courts and tribunals.
\end{abstract}

\section{Introduction}

It is difficult not to restate the obvious when one speaks of a multiplication of international courts and tribunals which has transformed the international legal order in recent decades. ${ }^{1}$ Yet, the importance of this phenomenon in terms of gradually paving the way for an international community adhering to the idea of the rule of law can hardly be overstated. Within the European polity one may refer to the examples of the ECJ, the ECHR, but also the EFTA Court, all associated with regional (economic) integration organisations. However, the proliferation of international courts has gone beyond the confines of regional integration

\footnotetext{
* Bernhard Hofstötter, University of Fribourg, Switzerland.

1 Cesare P.R. Romano, 'The Proliferation of International Tribunals: The Pieces of the Puzzle’ (1999) NYU JIL and Politics 709.
} 
organisations, as illustrated by the ICTY and the ICTR, ${ }^{2}$ the ICC ${ }^{3}$ and ITLOS, ${ }^{4}$ but also by an even more recent trend to establish so-called hybrid criminal tribunals which seek to marry the best (and actually sometimes the worst) of national and international law. ${ }^{5}$ Still, the more senior ICJ with its (potentially) all-encompassing jurisdiction over international law disputes enjoys pride of place as the 'principal judicial organ of the United Nations' (Article 92 UN Charter).

The more a legal system matures, the more it will provide for a developed hierarchy of norms, with ultimate system values finding expression in norms of superior rank, such as jus cogens, as well as a panoply of different avenues of dispute settlement. Both developments may be perceived as fostering the constitutionalisation of international law. ${ }^{6}$ At the same time, these largely compartmentalised developments ${ }^{7}$ may come at the price of a lack of systemic coherence, fragmentation, more frequent claims to self-containedness of sub-regimes and the constant striving of hierarchically equal international actors, including international courts and tribunals, to ensure their relevance and leave their imprints on the international plane. There are currently no mechanisms in play to mitigate these forces by means of hierarchy.

Whereas the very existence of different alternatives for dispute settlement is hardly a concern from the viewpoint of fragmentation, overlapping jurisdictions of international courts and tribunals 'activate' the problem by potentially giving rise to conflicting decisions which may put States into the awkward position of having to pick and choose which ruling to follow, or by providing a way for forum shopping. The case of the European Court of Justice (ECJ) may be special insofar as it is designed as the ultimate arbiter within the Community legal order (Article 220 EC)

2 These international criminal tribunals were set up by UNSC Res 827 (25 May 1993) UN Doc S/RES/827 and UNSC Res 995 (8 November 1994) UN Doc S/RES/995 respectively.

3 The ICC was established by the 1998 Rome Statute of the International Criminal Court, 2187 UNTS 90, which entered into force on 1 July 2002.

4 The 1982 UN Convention on the Law of the Sea (UNCLOS), 1833 UNTS 3, foresees in Part XV a comprehensive system for the settlement of disputes of which the International Tribunal for the Law of the Sea (ITLOS) forms part, its aim being to adjudicate disputes arising out of the interpretation and application of the Convention. Inaugurated in 1996 and with a mere 13 cases referred to it since then, ITLOS has remained a fairly invisible actor on the international stage.

5 James Cockayne, 'The Fraying Shoestring: Rethinking Hybrid War Crimes Tribunals' (2005) 28 Fordham ILJ 616, 619.

6 For a recent account, see Erika de Wet, 'The International Constitutional Order' (2006) 55 ICLQ 51.

7 See Karin Oellers-Frahm, 'Multiplication of International Courts and Tribunals and Conflicting Jurisdiction - Problems and Possible Solutions' (2001) Max Planck YB of UN Law 67, 72 . 
with, in general, compulsory jurisdiction over the EU Member States. ${ }^{8}$ This judicial monopoly on the interpretation of Community law is further hedged by Article 292 EC according to which Member States are obliged not to submit a dispute concerning the interpretation or application of the EC Treaty to any method of settlement other than those provided for in the Treaty. However, in the face of a multitude of international agreements concluded by the EC alone, or in conjunction with the EU Member States, the ECJ is increasingly confronted with the application and interpretation of treaties which may in turn provide for their own methods of dispute resolution.

Against this background, the recent case law related to Article 292 $\mathrm{EC}$, and the imminent danger of further instances of judicial conflicts, it is worth exploring the precise limits of the ECJ's judicial monopoly. How far do EU Member States retain competence to submit disputes relating to international law to arbitral tribunals? Once an international tribunal has been seized of a dispute, how may the ensuing problem of system conflict between the Community legal order as a purported 'new legal order of international law' and general international law be settled? In other words, what is the relationship between the micro-perspective of Community law and the macro-perspective of international law in terms of inter-state dispute settlement? After examining these issues, we will conclude by suggesting techniques to avoid conflict among international courts.

\section{Article $292 \mathrm{EC}$ in an age of multiple dispute settlement fora}

Article 292 EC has literally remained a dead letter in contentious proceedings before the ECJ until it reached the central stage in the Court's recent judgment in Commission $v$ Ireland ${ }^{9}$. Article 292 EC reads:

Member States undertake not to submit a dispute concerning the interpretation or application of this Treaty to any method of settlement other than those provided for therein. ${ }^{10}$

Put positively, this rather straightforward and unambiguous provision allows Member States to submit disputes to international courts and tribunals other than the ECJ only where they relate to rights and obligations which do not flow from the EC Treaty. Beyond this obligation not to pursue alternative avenues of dispute settlement, Article 239 EC gives

\footnotetext{
8 But see also Article $35 \mathrm{EU}$ which provides for an optional clause along similar lines to Article 38 of the ICJ Statute in the realm of the third pillar.

9 Case C-459/03 Commission v Ireland [2006] ECR I-4635.

10 Note that Article 193 EURATOM Treaty contains a similarly worded provision.
} 
the ECJ an optional jurisdiction in any dispute "which relates to the subject matter of this Treaty', if the Member States have chosen ad hoc to refer such a dispute to the ECJ. The answer to the question to what extent Member States must refrain from involving other international courts and tribunals consequently oscillates between disputes concerning the interpretation or application of the EC Treaty and disputes relating to the subject matter of the EC Treaty. Only in the former case are they barred from referring a case to alternative dispute settlement fora, whereas in the latter instance they fully retain their power under international law to settle their disputes peacefully by means of their choice (Article $33 \mathrm{UN}$ Charter).

Article 292 EC had only once surfaced in the Court's case law before Commission $v$ Ireland, namely in Opinion 1/91 with regard to the establishment of an EEA court competent to authoritatively interpret the EEA agreement for all the contracting parties to this agreement. There the Court ruled out the possibility of establishing a separate EEA Court, explaining that conferring jurisdiction on such a court

... is likely adversely to affect the allocation of responsibilities defined in the Treaties, and, hence, the autonomy of the Community legal order, respect of which must be assured by the Court of Justice pursuant to Article 164 EEC Treaty [now Article 220 EC]. This exclusive jurisdiction of the Court is confirmed by Article 219 EEC Treaty [now Article 292 EC], under which member states undertake not to submit a dispute concerning the interpretation or application of that treaty to any method of settlement other than those provided for in the Treaty. ${ }^{11}$

The rationale of Article $292 \mathrm{EC}$ is therefore linked with the autonomy of Community law which finds expression in its uniform interpretation and application, secured in the last instance by the judicial monopoly of the ECJ. ${ }^{12}$ As Barents explains, 'Articles 220 and $292 \mathrm{EC}$ both refer to the "interpretation and application" of the EC Treaty, as a result of which the Community courts are exclusively competent to "make" the law of the Community, thus confirming the principle, occasionally denied or criticised, "Curia locuta, causa finita". ${ }^{13}$

Needless to say, Article $292 \mathrm{EC}$ extends to Community law in toto, and thus includes both primary and secondary Community law as well

\footnotetext{
11 Opinion 1/91 [1991] I-6079 para 35.

12 Cf Marco Bronckers, 'The Relationship of the EC Courts with Other International Tribunals: Non-committal, Respectful or Submissive?' (2007) 44 CML Rev 601, 606.

13 René Barents, The Autonomy of Community Law (European Monograph Series, Kluwer, The Hague 2004) 288.
} 
as treaties concluded by the Community, and mixed agreements, since they form an integral part of the Community legal order, as far as they do not relate to an exclusive Member State competence. If one is mindful of a transformation of international law which has been brought about by the multiplication of international organisations predominantly inhabited by lawyers - international courts and tribunals - in particular after the end of the Cold War, it must come as less than a surprise that the actual relevance of Article $292 \mathrm{EC}$ is increasing. A number of dispute settlement mechanisms contained in mixed agreements have been ratified by the EC and the EU Member States. Examples of note include the UNCLOS or the OSPAR Conventions. Both provide for dispute settlement systems which do not explicitly foresee a role for the ECJ.

\section{Article $292 \mathrm{EC}$ in the MOX Plant dispute}

\section{A. History of proceedings}

The MOX plant dispute has involved two arbitral tribunals established under the OSPAR and UNCLOS conventions respectively, ITLOS as well as the ECJ. Its factual background is centred on the authorisation and operation of the MOX plant in Sellafield, Cumbria, a plant designed to convert plutonium from spent nuclear fuel into a fuel called MOX ${ }^{14}$ which is used as an energy source in nuclear power stations. The two arbitrations initiated by Ireland related to two distinct claims:

First, before an arbitral tribunal established under the OSPAR Convention, Ireland demanded the disclosure of all relevant information relating to radioactive discharges of the MOX plant pursuant to Article 9 of the OSPAR Convention, which requires states parties to make available information on the state of the maritime area and on activities or measures adversely affecting or likely to affect it (Article 9(1) and (2) OSPAR).

Second, Ireland alleged a violation by the United Kingdom of the environmental obligations incumbent on states parties to UNCLOS. More specifically, Ireland argued inter alia that the United Kingdom had failed to take the necessary measures to prevent, reduce and control pollution of the marine environment of the Irish Sea by discharges of radioactive materials and wastes originating from the MOX plant. An arbitral tribunal established under Article 287 UNCLOS $^{15}$ should adjudicate this latter set of claims.

\footnotetext{
14 An acronym for 'mixed oxide fuel'.

15 It is to be noted that Article 287 UNCLOS, whilst providing for compulsory dispute settlement, leaves the choice of means to the discretion of the parties. Thus, states may chose one or more of the following dispute settlement bodies: ITLOS, the ICJ and/or arbitral tribunals. Since in this case there was no common agreement on a more institutionalised form of dispute settlement between the parties, only arbitration could be resorted to.
} 


\section{B. The OSPAR award}

In its final award of 2 July $2003,{ }^{16}$ the arbitral tribunal dismissed the claims presented by Ireland, relying on a narrow interpretation of Article 9 of the OSPAR Convention. Although the tribunal was aware that the question of access to documents had connotations with European Community law, and in particular with Directive 90/313/EEC, ${ }^{17}$ it considered itself only competent to decide on the basis of the Convention. The tribunal reasoned that '[e]ach of the OSPAR Convention and Directive 90/313 is an independent legal source that establishes a distinct legal regime and provides for different legal remedies' ${ }^{18}$ In light of the more malleable wording of Article 32(5)(a) OSPAR which defines the law to be applied by arbitral tribunals and refers to the 'rules of international law and, in particular, those of the Convention', such a restrictive construction must come as a surprise. ${ }^{19}$ Equally, with regard to available dispute settlement avenues the arbitral tribunal sees the purportedly self-contained dispute resolution mechanism envisaged in Article 32 OSPAR Convention in complete isolation from the remedies available in the Community legal order.$^{20}$ The tribunal is therefore somewhat mindful of the problems surrounding Article $292 \mathrm{EC}$, but does not explicitly refer to this provision and errs in viewing the ECJ's potential role in terms of party choice only, therefore failing to appraise the constraining forces of Article $292 \mathrm{EC}$ for the Member States.

Even though at one point the tribunal claims to derive further support for its interpretation of Article 9 OSPAR Convention from the relevant rules of international law and European Union law, ${ }^{21}$ it does not actually take into account rights and obligations flowing from Community law in its award. The paradoxical result of its approach is that the dispute between two EU Member States is decided on the basis of international law only, leaving aside applicable secondary Community law which has been interpreted far more extensively by the ECJ.

\footnotetext{
16 OSPAR Arbitration (Ireland $v$ UK) (2003), available online at <http://www.pca-cpa.org/ showpage.asp?pag_id=1158> accessed 11 June 2007.

17 Council Directive (EEC) 90/313 on the freedom of access to information on the environment [1990] OJ L158/56, as subsequently replaced by Directive 2003/4 (EC) of the European Parliament and of the Council on public access to environmental information and repealing Council Directive 90/313/EEC [2003] OJ LA1/26.

18 OSPAR Arbitration (Ireland $v$ UK) (2003) para 142.

19 See also Nikolaos Lavranos, 'MOX Plant Dispute, Court of Justice of the European Communities' [2006] EuConst 456, 460.

20 OSPAR Arbitration (Ireland $v$ UK) (2003) para 143.

${ }^{21}$ OSPAR Arbitration (Ireland v UK) (2003) para 139.
} 


\section{The UNCLOS proceedings}

Before an arbitral tribunal had been established, Ireland had requested ITLOS inter alia to prescribe that the United Kingdom immediately suspend the authorisation of the MOX plant and ensure that no trans-border movements of radioactive substances or wastes take place. Pursuant to Article 290(5) UNCLOS, ITLOS may, pending the constitution of an arbitral tribunal, prescribe provisional measures in cases of urgency, if it considers that the arbitral tribunal to be constituted would have jurisdiction. By order of 3 December 2001, ITLOS affirmed prima facie jurisdiction and ordered both parties to cooperate and enter into consultations with regard to the potential environmental effects of the MOX plant on the Irish Sea. ${ }^{22}$ In so finding, ITLOS had not taken stock of the argument advanced by the United Kingdom, whereas Article 292 of the EC Treaty ruled out the jurisdiction of a tribunal set up under Annex VII of UNCLOS. ${ }^{23}$ In a separate opinion Judge Wolfrum squarely addressed the issue of Article $292 \mathrm{EC}$ and reasoned in blissful ignorance of the concept of mixed agreements that the Community law framework would not suggest that the ECJ was competent to decide on disputes concerning the interpretation and application of UNCLOS. ${ }^{24}$ Once the arbitral tribunal had been constituted in February 2002, it equally accepted its prima facie jurisdiction to decide the merits of the case. ${ }^{25}$ At the same time, however, it pointed to the necessity of arriving at a definitive conclusion whether or not it was endowed with jurisdiction, ${ }^{26}$ not least mandated by the objection on jurisdiction raised by the United Kingdom. The tribunal proved receptive of the UK's line of argument and recognised that the dispute related to matters essentially of concern to a separate legal order, namely the Community legal order, and had to be determined within the institutional framework of the latter. ${ }^{27}$ In spite of the risk of considerable delay, the tribunal could not firmly establish its jurisdiction with regard to all the claims presented until the Community law issues

22 MOX Plant Case (No 10) (Ireland v UK) (Provisional Measures, Order of 3 December 2001) available online at <http://www.itlos.org/start2_en.html> accessed 11 June 2007.

${ }^{23}$ MOX Plant Case (No 10) (Ireland $v$ UK) written response of the UK, paras $166 \mathrm{ff}$.

${ }^{24}$ MOX Plant Case (No 10) (Ireland $v$ UK) separate opinion of Judge Wolfrum, under heading 'Article 282 of the Convention'.

25 MOX Plant Case (Ireland $v$ UK) (Suspension of Proceedings on Jurisdiction and Merits, Order No 3 of 24 June 2003), para 14; available online at <http://www.pca-cpa.org/showpage.asp?pag_id=1148> accessed 11 June 2007.

26 MOX Plant Case (Ireland $v$ UK) (Suspension of Proceedings on Jurisdiction and Merits, Order No 3 of 24 June 2003) para 15.

27 MOX Plant Case (Ireland $v$ UK) (Suspension of Proceedings on Jurisdiction and Merits, Order No 3 of 24 June 2003) para 24. 
had been definitively resolved by the ECJ. ${ }^{28}$ Consequently, it decided to suspend the proceedings, implicitly inviting the parties to settle the outstanding issues before the ECJ. In further motivating its decision the tribunal explained:

In the circumstances, and bearing in mind considerations of mutual respect and comity which should prevail between judicial institutions both of which may be called upon to determine rights and obligations as between two States, the Tribunal considers that it would be inappropriate for it to proceed further with hearing the Parties on the merits of the dispute in the absence of a resolution of the problems referred to. Moreover, a procedure that might result in two conflicting decisions on the same issue would not be helpful to the resolution of the dispute between the Parties. ${ }^{29}$

\section{The judgment of the ECJ}

Even before the beginning of the oral pleadings before the UNCLOS arbitral tribunal, it had become known that the European Commission was contemplating instituting infringement proceedings under Article 226 EC. This had raised the tribunal's fear of two possibly conflicting decisions which would be unhelpful to the parties seeking resolution of their dispute,,$^{30}$ and obviously contributed to its decision to stay proceedings. The imminent danger of the Commission starting proceedings finally materialised at around the time when the UNCLOS arbitral tribunal rendered Order No. $3{ }^{31}$ The Commission based its argument on the following heads of complaint: by bringing proceedings under UNCLOS, Ireland had failed to respect the exclusive jurisdiction of the Court as enshrined in Article 292 EC as well as the corresponding provision in the EURATOM Treaty. Moreover, it had violated its duty of cooperation under Article 10 EC as it had failed to inform and consult with the Commission.

The Court started by pointing out that, from the viewpoint of the Community legal order, UNCLOS is a mixed agreement which shares the same legal characteristics as agreements concluded by the Community alone. Thus, according to settled case law its provisions form an integral

\footnotetext{
28 MOX Plant Case (Ireland $v$ UK) (Suspension of Proceedings on Jurisdiction and Merits, Order No 3 of 24 June 2003) para 25.

29 MOX Plant Case (Ireland $v$ UK) (Suspension of Proceedings on Jurisdiction and Merits, Order No 3 of 24 June 2003) para 28.

30 MOX Plant Case (Ireland $v$ UK) (Suspension of Proceedings on Jurisdiction and Merits, Order No 3 of 24 June 2003) paras 21 and 28.

31 Robin Churchill and Joanne Scott, 'The MOX Plant Litigation: The First Half-Life' (2004) 53 ICLQ 643, 656.
} 
part of the Community legal order. ${ }^{32}$ As Article 292 EC only establishes a judicial monopoly of the ECJ with regard to the interpretation and application of the Treaty, the Court went on to examine whether the provisions of UNCLOS at issue - essentially those relating to marine environmental pollution - relate to a competence exercised by the Community. Referring to a number of directives adopted in the field, it concluded that 'the matters covered by the provisions of the Convention relied on by Ireland before the Arbitral Tribunal are very largely regulated by Community measures'. ${ }^{33}$ Consequently, in applying its long-standing ERTA jurisprudence, ${ }^{34}$ the Court held that the provisions of UNCLOS invoked by Ireland before the arbitral tribunal come within the scope of Community competence and form part of the Community legal order, in turn triggering the Court's jurisdiction. ${ }^{35}$

Next, the Court turned to the question whether its jurisdiction could be considered exclusive in light of the dispute settlement system provided for by UNCLOS. Here, the Court reiterated its approach expounded in Opinion 1/91 according to which international agreements cannot affect the allocation of responsibilities defined in the Treaties and thus the autonomy of the Community legal system. The Court found confirmation of the exclusivity of its jurisdiction in Article 292 EC. ${ }^{36}$ Whereas one could therefore expect that the Community system of judicial protection, more precisely Article $227 \mathrm{EC}$, would simply override the dispute settlement provisions in UNCLOS, the Court found a stepping stone for a more harmonious interpretation in Article 282 UNCLOS, which contains a conflict of jurisdictions clause. If the parties to a dispute 'have agreed, through a general, regional or bilateral agreement or otherwise' to a particular procedure entailing a binding decision, this procedure shall take precedence over the normal procedure provided for in UNCLOS. Thus, the Court found that UNCLOS itself is amenable to an interpretation avoiding a breach of the Court's exclusive jurisdiction. ${ }^{37}$

In sum, the Court found Ireland precluded from initiating proceedings before the arbitral tribunal in light of its own exclusive jurisdiction. ${ }^{38}$ As the Court explains, just the manifest risk that the jurisdictional order laid down in the Treaties and, consequently, the autonomy of the Community legal system, may be adversely affected is sufficient for finding a

\footnotetext{
32 Case C-459/03 Commission v Ireland [2006] ECR I-4635 paras 82-84.

33 Case C-459/03 Commission v Ireland [2006] ECR I-4635 para 110.

34 Case 22/70 Commission v Council [1971] ECR 263.

35 Case C-459/03 Commission v Ireland [2006] ECR I-4635 paras 120-121.

36 Case C-459/03 Commission v Ireland [2006] ECR I-4635 para 123.

37 Case C-459/03 Commission v Ireland [2006] ECR I-4635 para 124.

38 Case C-459/03 Commission v Ireland [2006] ECR I-4635 para 133.
} 
breach of Article 292 EC, ${ }^{39}$ regardless of whether or not an arbitral tribunal has been called upon to actually pronounce on a rule of Community law. In a most important obiter dictum the Court explains: 'It is for the Court, should the need arise, to identify the elements of the dispute which relate to provisions of the international agreement in question which fall outside its jurisdiction. ${ }^{40}$ In other words, the Court clearly reserves for itself a compétence de la compétence of sorts to determine the outer limits of its exclusive jurisdiction, and in this way hedges its pre-eminence over international arbitral tribunals.

With regard to the alleged breach of the duty of consultation and information with the Community institutions pursuant to Article $10 \mathrm{EC}$, the Court notes an obligation of Member States for consultation prior to instituting dispute settlement proceedings, which Ireland failed to observe. $^{41}$

\section{The death of inter-state arbitration in the EU, but did the ECJ get it right?}

\section{A. An extensive interpretation of Article 292 EC}

In its insistence on a broad scope of application for Article 292 EC, the judgment in Commission $v$ Ireland must have come as less than a surprise to a student of the Court's case law. Still, the paucity of authorities on the exact implications of Article 292 EC could leave some room for doubt, which the Court by now has filled with well-rehearsed arguments based on the need to preserve the autonomy of Community law. The ECJ has opted for a sweeping interpretation of Article $292 \mathrm{EC}$, thus emphasising the effet utile of Article $292 \mathrm{EC}$ which hedges the exclusive jurisdiction of the Court. This is apparent from at least three aspects of the Court's judgment:

First, with regard to its competence to interpret provisions of mixed agreements, the Court has proved consistently unwilling to enter into discussions about the exact attribution of a particular treaty provision to the two spheres of competences. In fact it is one of the virtues of mixed agreements to help avoid complicated delineation of power exercises ${ }^{42}$ Instead, the Court has opted to take on broad interpretative powers whenever a mixed agreement concerns a field largely covered by Community law. ${ }^{43}$ In

\footnotetext{
39 Case C-459/03 Commission v Ireland [2006] ECR I-4635 para 154-156.

40 Case C-459/03 Commission v Ireland [2006] ECR I-4635 para 135.

41 Case C-459/03 Commission v Ireland [2006] ECR I-4635 paras 172-182.

42 Piet Eeckhout, External Relations of the European Union - Legal and Constitutional Foundations (Oxford EC Law Library, OUP, Oxford 2004) 236.

43 Koen Lenaerts and Piet van Nuffel, Constitutional Law of the European Union $\left(2^{\text {nd }}\right.$ edn Sweet \& Maxwell, London 2005) 6-014.
} 
Commission $v$ Ireland, however, the Court for the first time explicitly assumes that it alone is competent to decide in case of doubt if a part of an agreement falls within Community competence. ${ }^{44}$ Thus, it would appear that Member States are precluded from letting arbitral tribunals examine this question first. Therefore, Member States which eschew the risk of subsequent Commission-initiated infringement proceedings will have to bring inter-state infringement actions before the ECJ whenever an issue appears to be covered by Community law. This way, the ongoing proliferation of mixed agreements in the Community legal order will allow the Court a firm say in their interpretation and application.

Second, this finding is corroborated by the accentuated duty of consultation and information with the Community institutions prior to instituting proceedings before an arbitral tribunal. It is probably not an oversight that the Court in paragraph 179 refers to the Community institutions wholesale, and not just to the Commission, as the Member States' interlocutors with regard to their obligation as per Article 10 EC. Since the notion of Community institution is inclusive of the Court (cf Article $7 \mathrm{EC}$ ), this means that the duties flowing from Article $10 \mathrm{EC}$ include consultation with the ECJ in the framework of (contentious) proceedings, before an arbitral tribunal may be established. ${ }^{45}$ In this sense, Article 10 EC feeds back into the Court's expansive interpretation of Article 292 EC and yet again vigorously asserts the Court's relevance in the interpretation of international agreements.

Third, the Court is satisfied with a 'manifest risk' of a referral to an arbitral tribunal impinging on the autonomy of the Community legal system. By focusing on a potential instead of an actual trespass into the Community judicial system, again the freedom of Member States to submit disputes to arbitral tribunals is significantly curtailed.

As is apparent from these considerations, one cannot but understand the judgment in Commission $v$ Ireland as essentially preserving the Court's exclusive jurisdiction. By the same token, however, one may wonder why the Court opts for linking Article 292 EC with Community competences at all. After all, Article 292 EC does not appear to necessarily require such a link, as it merely refers to the interpretation or application' of the Treaty. Whether a given question concerns the interpretation or application of the Treaty is not primarily an issue of competence, although competence may give guidance whether or not the Treaty applies. We see a similar approach, albeit not consistently, in the Court's case

44 Nikolaos Lavranos, 'MOX Plant Dispute, Court of Justice of the European Communities' [2006] EuConst 456, 465.

45 Nikolaos Lavranos, 'MOX Plant Dispute, Court of Justice of the European Communities' [2006] EuConst 456, 465. 
law on Union citizenship, where the Court at times examines pertinent Community competences in order to decide whether or not the prohibition of discrimination based on Article $12 \mathrm{EC}$ is applicable ${ }^{46}$ as the latter presupposes the applicability of EC law. ${ }^{47}$ It is thus conceivable that the ECJ would have sidestepped the competence issue, reasoning instead as it would normally do in connection with mixed agreements - that it has competence to interpret mixed agreements regardless of whether their provisions relate to the Community or Member States sphere of competence. ${ }^{48}$ This jurisdiction would then eo ipso be elevated to an exclusive jurisdiction by means of Article 292. It is therefore arguable that in spite of advocating an expansive interpretation of Article $292 \mathrm{EC}$, the Court has not opted for a maximum solution in Commission $v$ Ireland, walking along the rather stable competence path instead of interpreting Article $292 \mathrm{EC}$ as free from competence implications. The judgment is, of course, unrevealing as to why the Court proceeded as it did, but elements of judicial comity vis-à-vis international judicial actors may have played a role.

Needless to say, the Court's expansive construction of Article 292 EC has immediate repercussions on the conformity with EC law of interstate arbitration between EU Member States which must be considered as practically defunct after Commission $v$ Ireland. This begs the question if the solution expounded by the Court is viable, given that in an internationalist perspective the ECJ is just a regional actor and thus but a fraction of the international system of dispute settlement.

\section{B. Hic sunt leones - International Courts and Tribunals as a threat to the autonomy of Community law?}

Since the inception of its judicial activity, the ECJ has underscored the sui generis nature of the Community legal order. By pointing out

\footnotetext{
46 See, for instance, Case C-209/03 Dany Bidar [2005] ECR I-21 19 paras 39-43.

47 Article 12 EC reads: 'Within the scope of application of this Treaty, and without prejudice to any special provisions contained therein, any discrimination on grounds of nationality shall be prohibited' (emphasis added).

48 The link with Community competence is already missing in the Court's early case law on its jurisdiction to interpret mixed agreements, such as in Demirel, where the Court in interpreting a provision of the association agreement with Turkey held that the question whether it was competent to rule on a provision falling under Member State competence did not arise (Case 12/86 Demirel [1987] ECR 3719 paras 6-12). In the later Hèrmes (Case C-53/96 Hèrmes [1998] ECR I-3603) and Christian Dior (Joined Cases C-300/98 and C392/98 Christian Dior [2000] ECR I-11307) cases, again the competence issue was not applied as a criterion for the Court's jurisdiction. At the same time, one may argue that the relevance of the allocation of competences between the Community and the Member States for the extent of the Court's jurisdiction is simply 'left in the dark', without definitively denying its relevance. See Piet Eeckhout, External Relations of the European Union - Legal and Constitutional Foundations (Oxford EC Law Library, OUP, Oxford 2004) 271. I am grateful to Professor Marise Cremona for this point.
} 
that Community law forms a 'new legal order of international law', ${ }^{49}$ the Court has managed to secure the relevance of the former in the national legal orders and thereby tamed the disruptive forces of national laws to the postulated autonomy of the 'new law'. In this sense, the argument of a new legal order lays the discursive foundation for the transformatory doctrines of supremacy and direct effect. ${ }^{50}$ Again underscoring the sui generis nature of Community law, the Court later identified the EC Treaty as the constitutional charter of the Community. ${ }^{51}$ Whereas insistence on the autonomy of the Community legal order was crucial in order to position Community law vis-à-vis national law as more than a 'diplomatic law' of sorts which would be sufficiently malleable not to stand in the way of later 'derogations' by national law, ${ }^{52}$ international law seemed less of a threat to the Community legal order. Unprecedented in its scope of rights granted to individuals, there was hardly any room for conflict with international law, save perhaps with fundamental rights, a debate to burgeon only later. Indeed, the reference to international law in van Gend \& Loos had little to do with positioning Community law within the global framework of international law. ${ }^{53}$ Rather, it was about teaching national courts a lesson on how Community law was to be applied by referring to terms familiar to them: regardless of the perennial controversies between monists and dualists, Community law was to be invoked before national courts, and in addition was to take the supreme position in the national hierarchies of norms, even to the detriment of national constitutional law. ${ }^{54}$

In Commission $v$ Ireland, the Court arguably catches up on positioning Community law vis-à-vis international law, which seemed of no avail in the early causes célèbres. It is not by coincidence that a case of classic

\footnotetext{
49 Case 26/62 Van Gend \& Loos [1963] ECR 1 para 12.

50 Instead of many, see J.H.H. Weiler, 'The Transformation of Europe', in J.H.H. Weiler, The Constitution of Europe - 'Do the New Clothes Have an Emperor?' and other Essays on European Integration (CUP, Cambridge 1999) 10, 16 [reprint of $100 \mathrm{YLJ}$ (1991) 2403].

51 Case 294/83 Les Verts [1986] ECR 1339 para 23.

52 This was the issue in Case 6/64 Costa/ENEL [1964] 585.

53 At any rate, in light of the 'individualizing potential' of international law as elaborated by the PCIJ in its advisory opinion on the jurisdiction of the Courts of Danzig (Jurisdiction of the Courts of Danzig (Advisory Opinion) PCIJ Rep Series B No 15), the juxtaposition of international law and Community law in van Gend \& Loos was predicated on a not fully accurate depiction of international law: whereas the scope and breadth of the involvement of the individual was unprecedented in Community law, the idea of an international agreement granting rights to individuals which they could then invoke before national courts was by no means new in the 1960s and could thus not be the hallmark of the "new legal order of international law'. For this point, see Bernhard Hofstötter, Non-Compliance of National Courts - Remedies in European Community Law and Beyond (T.M.C. Asser Press, The Hague 2005) 14.

54 Case 106/77 Simmenthal [1978] ECR 629 para 24.
} 
inter-state arbitration between two EU Member States - an area where overlaps with the Community legal order are potentially great - gave rise to the Court's attempt at delimitation. In short, the Court extends the autonomy argument to the relationship with international law. ${ }^{55}$ At first sight, this may be rather unsurprising as we could interpret the early judgments also in the sense that although they contain reactions to national law, they still proclaim the autonomy of Community law in an all-embracing fashion. But then such a reading had to seem unlikely, given that quite different stakes are involved in defining the relationship between Community law and national law on the one hand, and between Community law and international law, on the other. The issue of international inter-court relationships surfacing in Commission $v$ Ireland illustrates this well. Few would doubt that a host of rulings by national courts of last instance disrespectful of the role attributed to the ECJ by Article 234(3) EC as well as substantively non-compliant with Community law, as interpreted by the ECJ, would be disruptive of the coherence and, thus, the autonomy of Community law. On the other hand, isolated instances of judicial non-compliance ${ }^{56}$ in the case law of national constitutional courts, in particular, could hardly upset the coherence and overall effectiveness of the Community legal order. Against this background, it is far from clear that isolated awards rendered by arbitral tribunals would have to be perceived as a systemic threat to coherence. But if the autonomy of the Community legal order is not actually at stake, a more liberal reading of Article $292 \mathrm{EC}$ would not be ruled out. The terra incognita of international arbitration possibly inhabited by lions (leones) liable to put in jeopardy the autonomy of the Community legal order alongside the Court's judicial monopoly of interpretation may thus not be in need of being policed in the manner put forward by the Court.

It is apparent that the ECJ follows the logics of an internal perspective and consequently opts for a far-reaching hedging of its prerogatives. By contrast, the external perspective brought into the picture by the involvement of arbitral tribunals set up under international agreements only marginally affects the Court's reasoning. In its emphasis on a perspective intrinsic to the Community legal order, the Court underlines its role as a constitutional court whose task is the preservation of the autonomy of the Community legal order. There is no room left for any other international courts or tribunals, once a link with Community law - however tenuous - has been established. In its focus on an internal perspective, the Court's self-perception is akin to that of national constitu-

55 Nikolaos Lavranos, 'MOX Plant Dispute, Court of Justice of the European Communities' [2006] EuConst 456, 464.

56 Such as for instance the (by now historical) denial of direct effect by the French Conseil d'Etat in Cohn-Bendit (1979) RTDE 175. 
tional courts vis-à-vis the ECJ itself, which still prove relatively reluctant to refer questions for preliminary rulings to the Court, in spite of their duty to do so under Article 234(3) EC. ${ }^{57}$ The same goes for the by now historical controversies between the ECJ and the German Constitutional Court with regard to the contested supremacy of Community law in light of the absence of a written catalogue of fundamental rights.

With this in mind, the judgment in Commission $v$ Ireland may be counted among the grand constitutional rulings rendered by the ECJ. From an international law perspective, the balance sheet appears more ambiguous, however. The ECJ is not only a constitutional court but rather hybrid in nature, combining features of domestic and international courts. ${ }^{58}$ With regard to its function as a court of international law, the Court arguably ignores the external perspective and consequently the fact that from the international law perspective it is but one among a steadily growing number of judicial actors. In relying exclusively on the logics inherent in Community law, it purports as self-evident something which is far from self-evident, namely, it implies a judicial hierarchy in international law with itself on top. Such a hierarchy is unknown to international law, however. As can be gleaned from Commission $v$ Ireland, the ECJ's answer to conflicting jurisdictions of international courts appears to be to refer to the logics of European integration. Although compelling and literally unchallengeable as an argument intrinsic to the Community legal order, its argumentative force is much weaker outside the Community law context. Although binding on the Member States, Article 292 EC is assuredly not binding on other international courts and tribunals.

In line with conceptualising Community law as a new legal order of international law, we may also read a narrative of progress in Commission $v$ Ireland. Inter-state arbitration has come on us as the oldest of the legal methods of dispute settlement, conventionally traced back to the 1794 Jay Treaty. ${ }^{59}$ In its more modern form, the constitutive instruments of the Permanent Court of Arbitration, namely the 1899 Hague Convention for the Pacific Settlement of Disputes revised by the 1907 Convention of the same denomination, date from the turn of the last century. The origins of inter-state arbitration are thus to be found in an era of largely unabated state sovereignty which finds reflection in arbitration as a fairly flexible means of dispute settlement, leaving many choices to be made by the

\footnotetext{
57 See Karen Alter, Establishing the Supremacy of European Law (Oxford, OUP 2001) 54 and Bernhard Hofstötter, Non-Compliance of National Courts - Remedies in European Community Law and Beyond (T.M.C. Asser Press, The Hague 2005) 165.

58 Cesare P.R. Romano, Case note on Case C-459/03 Commission v Ireland (2007) 101 AJIL 171, 175.

59 John Merrills, 'The Means of Dispute Settlement' in Malcolm D. Evans (ed), International Law ( $2^{\text {nd }}$ edn OUP, Oxford 2006) 533, 542.
} 
states parties. This, in turn, might be perceived as fitting uneasily with 'a new legal order of international law', which has stripped the core of state sovereignty to its minimum. And yet, from the viewpoint of the Member States there are clear advantages associated with arbitration: one may mention speed which, in light of the average duration of proceedings before the ECJ of roughly two years, ${ }^{60}$ may see Member States turn elsewhere. Another issue is confidentiality which may lead Member States to possibly secretive arbitration. Most importantly, the possibility of freely appointing the arbitrators will secure the appeal of arbitration for Member States. Member States may also view the institutional shortcomings of arbitration as appealing which, by contrast to the by now smoothly operating Article 228 EC-arrangement, ${ }^{61}$ have no enforcement mechanism in place. On the other hand, this must not really be a concern for the ECJ, since once Member States fail to honour their obligations under the Treaty by not respecting an arbitral award, infringement proceedings are obviously an option.

Coming back to the responses to the problem of multiple jurisdictions by both the ECJ and the arbitral tribunal under UNCLOS, we may discern two different approaches, irreconcilable with one another. In Commission $v$ Ireland, the ECJ opts for an expansive interpretation of its own jurisdiction predicated on preserving the autonomy of the Community legal order. By contrast, the reasoning of the arbitral tribunal under UNCLOS is characterised by diplomatic self-restraint. In addition, the arbitral tribunal proves to be mindful of the jurisdictional implications of the legal environment in which it is operating. Arguably, the approach deployed by the arbitral tribunal fits better with the characteristics of an international legal order which cannot rely on a hierarchically organised judicial system. By the same token, the internal perspective adopted by the ECJ is well-suited to preserve the autonomy of the Community legal order. At the same time, however, preserving the autonomy of the Community legal system as one of the ultimate values of the jurisprudence of the ECJ may come at the paradoxical price of triggering the fragmentation of international law. The ruling of the ECJ is remarkably silent on this point, whereas international lawyers seem to be increasingly disgruntled by the

\footnotetext{
60 ECJ, Annual Report for 2006, Proceedings of the Court of Justice, Section A.2. Mention, however, has to be made of the fact that the average length of proceedings has decreased in recent years. The average duration of proceedings in connection with preliminary rulings amounted to 19.8 months in 2006, as compared to 23.5 months in 2004 and 20.4 months in 2005. With regard to direct actions, the average duration was 20 months in 2006 (21.3 months in 2005).

61 As activated for the first time in Case C-387/97 Commission v Greece [2000] ECR I-5047; on the subsequent developments in the Court's case law, see Ian Kilbey, 'Financial Penalties under Article 228(2) EC: Excessive Complexity?' (2007) 44 CML Rev, 743 and Pal Wennerås, 'A New Dawn for Commission Enforcement under Articles 226 and 228 EC' (2006) 43 CML Rev 31.
} 
disruptive forces of Community law on international law. ${ }^{62}$ In particular, the ECJ's non-deferential attitude with regard to rulings stemming from the WTO dispute settlement system which the Court regularly refers to as essentially diplomatic in nature continues to raise some eyebrows. ${ }^{63}$ In this context, it is noteworthy that the current debate on the fragmentation of international law has as it root conflicting decisions by international courts, a fact which has been lamented by former presidents of the ICJ in their annual reports to the UN General Assembly. ${ }^{64}$

\section{MOX Plant as an easy case}

In the end, however, the outcome of the ruling in Commission $v$ Ireland seems commendable. This is due to the fact that the dispute settlement system foreseen by UNCLOS entails a great degree of flexibility which is able to accommodate more specific procedures agreed by the parties to a dispute. First, Article 287(5) UNCLOS provides for arbitration as the default dispute settlement mechanism. Only when two parties to a dispute have not opted for the same procedure, essentially such as referring the dispute to the ICJ or ITLOS, will arbitration come into play, 'unless the parties otherwise agree'. Second, more explicitly, Article 282

\footnotetext{
62 Although the International Law Commission's Study Group on 'Fragmentation of International Law: Difficulties Arising from the Diversification and Expansion of International Law' deliberately decided to stand clear of the institutional issues of fragmentation and thus deplorably missed the opportunity to further stimulate the debate on jurisdictional conflict, this attitude can be gleaned overall from the ILC's Analytical Study. So, the Study Group is fairly critical of 'disconnection clauses', for instance, which are meant to ensure the continuing application of Community law rules between the EU Member States parties to a multilateral treaty and consequently insulating Community law rules within the framework of an international agreement. In the words of the ILC, '[w] hat may seem disturbing about such clauses is that they are open to only some parties to the original treaty and the content of the Community law to which they refer may be both uncertain and subject to change' (ILC, 'Fragmentation of International Law: Difficulties Arising from the Diversification and Expansion of International Law', Report of the Study Group of the ILC, para 292). The Study Group goes on as follows: 'Like inter se modification, a disconnection clause makes it possible for a limited group of parties to enhance the objectives of the treaty by taking measures that correspond to their special circumstances. But just like inter se agreements, this practice creates the possibility of undermining the original treaty regime. ... From the perspective of other treaty parties, the use of disconnection clause might create double standards, be politically incorrect or just confusing' (Report of the Study Group, para 293). With a view to the MOX Plant dispute, reserving to the ECJ an exclusive jurisdiction ultimately results in 'a distinctively European take on UNCLOS' (Robin Churchill and Joanne Scott, 'The MOX Plant Litigation: The First Half-Life' (2004) 53 ICLQ 643, 669) with similarly disruptive forces as exhibited by disconnection clauses.

63 See the judgments in Case C-377/02 Van Parys [2005] ECR I-1465, paras 42 et seq., and Case T-19/01 Chiquita [2005] ECR II-315, paras 156 et seq. In both cases the Court rejects private damage claims relying on antecedent WTO rulings finding Community law in breach of WTO rules.

64 Cf Martti Koskenniemi and Päivi Leino, 'Fragmentation of International Law? Postmodern Anxieties' (2002) 15 LJIL 553.
} 
UNCLOS allows for the accommodation of other dispute settlement provisions yielding binding decisions which have been agreed upon between the parties to a dispute. The wording of Article 282 which, again very broadly, refers to general, regional or bilateral agreements or other forms of agreements, may thus easily 'receive' the exclusivity of the Community judicial system qua regional agreement. As far as can be seen, such an interpretation is also in line with the other methods of treaty interpretation commonly agreed in international law. ${ }^{65}$ Consequently, the Court was confronted with an easy case in Commission $v$ Ireland since UNCLOS itself provided an avenue to avoid trespassing into the competences of other courts or tribunals. Against this background, the Court could satisfy itself with giving an easy answer based on an approach intrinsic to the Community legal order, without having to fully explore the international legal implications of the problem of multiplied international jurisdictions.

However, not all international treaties concluded by the EC in conjunction with the EU Member States may be that receptive to the peculiarities of the Community legal system. This would apply particularly to treaties providing for their own compulsory dispute settlement systems. ${ }^{66}$ Clearly, also in this instance, the initiative to start proceedings would lie with the interested state party which would therefore enjoy a degree of 'choice' whether to have recourse to the dispute settlement system provided for in a treaty, or rather to involve the ECJ. In such cases of a treaty-based dispute settlement system displaying less flexibility than Article 282 UNCLOS, the states concerned would be squeezed between two competing legal obligations and consequently would have to decide which obligation to respect and which one to violate. For this category of case, the judgment in Commission $v$ Ireland does not provide a workable solution, apart from the precepts of respecting the ECJ's judicial monopoly. Arguably, in an era where we are coming ever closer to a compulsory paradigm in dispute settlement in international law, ${ }^{67}$ this category of cases will gain in relevance. On the other hand, also Article 32 OSPAR, for instance, would allow for sufficient flexibility to accommodate a wide scope of jurisdictional competence of the ECJ, as it refers to the possi-

65 See Article $31 \mathrm{ff}$ of the 1969 Vienna Convention on the Law of Treaties.

66 Interestingly, the compulsory jurisdiction of ad hoc panels or the standing Appellate Body to decide on any dispute with regard to the implementation of the WTO agreements has received no attention at all in the ECJ's Opinion 1/94. See Marco Bronckers, 'The Relationship of the EC Courts with Other International Tribunals: Non-committal, Respectful or Submissive?' (2007) 44 CML Rev 601, 610. On Opinion 1/94 in general, cf Meinrad Hilf, 'The ECJ's Opinion on the WTO - No surprise, but wise?' (1995) 6 EJIL, 1.

67 See Cesare P.R. Romano, 'From the Consensual to the Compulsory Paradigm in International Adjudication: Elements for a Theory of Consent' (2006) NYU Public Law and Legal Theory Working Paper 20 <http://lsr.nellco.org/cgi/viewcontent.cgi?article=1019\&context =nyu/plltwp $>$ accessed 11 June 2007 . 
bility of parties agreeing otherwise to settle their disputes (Article 32(2) OSPAR). Therefore, one can only speculate about the reasons why the Commission did not commence infringement proceedings against Ireland for initiating arbitration under the OSPAR convention, since also Article 32 OSPAR would make for a relatively easy case.

\section{Practical Limitations of the ECJ's approach}

Given the continuing appeal of referring cases to arbitration for the EU Member States as sketched out above, the issue of the enforcement of the Court's broad judicial monopoly needs to be addressed. Since Member States have proved wary of starting infringement proceedings against their peers, ${ }^{68}$ the key role in enforcing the Court's judicial monopoly lies with the Commission. However, even if the Commission decides to actually start infringement proceedings, the average length of proceedings before the ECJ will often mean that a judgment finding a violation of Article 292 EC comes too late, that is after an award has been rendered by an arbitral tribunal. This at least assuming that not all international judicial actors will adopt a similarly diplomatic stance predicated on judicial comity as the arbitral tribunal under UNCLOS did, but rather opt for a more assertive role along the lines of the OSPAR tribunal's approach in MOX plant.

This insight may already provide us with a key to understanding the policy rationale behind the Commission's approach, whereas firm conclusions would be premature in light of the limited number of cases involving Article $292 \mathrm{EC}$ as of yet. It is conceivable that the Commission actually eschews bringing up cases of jurisdictional conflict where it is likely that a ruling of the ECJ would come too late, that is, after an award has been rendered. The reason is that under these circumstances finding a violation of Article $292 \mathrm{EC}$ would undermine the authority of the arbitral award, potentially amount to a weakening and an embarrassment of the international system of dispute settlement as a whole, and put on the spot the vexed issue of jurisdictional conflict. With regard to proceedings before the OSPAR arbitral tribunal, the Commission had been informed by the Executive Secretary of the commission established under the OSPAR convention about the ongoing proceedings. ${ }^{69}$ Even though the Commission had called on Ireland to suspend OSPAR proceedings, it took no further steps after its call had remained unanswered. ${ }^{70}$ On the other hand, the danger of conflicting decisions cannot materialise once an ar-

\footnotetext{
68 Koen Lenaerts and Dirk van Arts, Procedural Law of the European Union $\left(2^{\text {nd }}\right.$ edn Sweet \& Maxwell, London 2005) 5-029.

69 Case C-459/03 Commission v Ireland [2006] ECR I-4635 para 49.

70 Case C-459/03 Commission v Ireland [2006] ECR I-4635 para 50. Instead of suspending proceedings, Ireland instituted a second set of proceedings under UNCLOS.
} 
bitral tribunal has decided to stay proceedings, with the ECJ then being able to settle the jurisdictional issue first, without risking contradictory decisions which, although they may be smoothed out internally by reference to the doctrine of supremacy, cannot be squarely resolved on the international plane. So, with regard to the arbitral tribunal under UNCLOS in MOX plant there was no imminent danger that an arbitral award could predate the Court's judgment, since proceedings had already been stayed by means of order No 3 of 24 June 2003. This reading of the Commission's approach is confirmed by its action in the Iron Rhine $e^{71}$ case, although only on a superficial reading. Iron Rhine, a dispute between Belgium and the Netherlands about the reactivation of an old railway line involving certain aspects of EC environmental law, saw close consultations between the parties to the dispute and the Commission in order to adequately delimit the subject matter of the dispute in light of Article 292 EC. ${ }^{72}$ In spite of the parties being at pains to avoid submitting Community law aspects to the established arbitral tribunal, in the end the arbitrators went to some length to explain why in their view Community law was not applicable. ${ }^{73}$ In addition, the tribunal came up with a fairly curious reading of the CILFIT criteria, considering itself in a position analogous to a national court potentially under a duty to refer questions for preliminary rulings to the ECJ ${ }^{74}$ The tribunal thus linked the question of the applicability of Community law with the entirely different aspect related to how far a national court of last instance could be released from its duty to refer. Despite the obvious shortcomings in the tribunal's reasoning from the point of view of Community law, the Commission's decision not to start infringement proceedings appears to have been motivated by the maxim of venire contra factum proprium instead of the danger of an ECJ ruling coming too late. Having consulted closely with the parties to the proceedings prior to an award being rendered, and therefore - at least implicitly - underwritten their course of action, it would have been unthinkable for the Commission to later start infringement proceedings without going against the legitimate expectations of compliance with Community law which it had created in the parties.

\footnotetext{
71 Iron Rhine Arbitration (Belgium $v$ Netherlands) (Award of 24 May 2005) <http://www.pcacpa.org/showpage.asp?pag_id=1155> accessed 11 June 2007. For a detailed account of the Community law implications of this case, see Ineke van Bladel, 'The Iron Rhine Arbitration Case: On the Right Legal Track?' (2005) Hague YBIL, 3.

${ }^{72}$ Ineke van Bladel, 'The Iron Rhine Arbitration Case: On the right legal track?' (2005) Hague YBIL 3, 20.

73 Iron Rhine Arbitration (Belgium v Netherlands) (Award of 24 May 2005) paras 97-141.

74 Paul James Cardwell and Duncan French, 'Who Decides? The ECJ's Judgment on Jurisdiction in the MOX Plant Dispute' (2007) 17 JEL 121, 127; Nikolaos Lavranos, 'The MOX Plant and IJzeren Rijn Disputes: Which Court Is the Supreme Arbiter?' (2006) 19 LJIL 223, 238.
} 
Thus, against this background it is arguable that the Commission is indeed aware of the problem of possibly conflicting rulings by the ECJ and other international courts, and keenly avoids such conflicts by being most selective in starting infringement proceedings. In this respect, the Commission's approach mirrors the diplomatic approach deployed by the arbitral tribunal established under UNCLOS in being mindful of avoiding actual conflicts between jurisdictions. Without doubt, this position is open to abuse, since Member States will only need to appoint speedy arbitrators to effectively escape from the Court's judicial monopoly.

\section{Conclusions}

It is remarkable that the issues underlying Article 292 EC have cropped up almost simultaneously in two recent cases revolving around the permissibility of inter-state arbitration involving EU Members States, despite the implications of Article 292 EC. This confirms the actual relevance of the phenomenon of a multiplication of judicial actors and the ensuing judicialisation of international law, which does not stop short of reaching out to regional integration organisations. In the absence of a hierarchy between all the judicial actors in place and in light of recent jurisdictional conflicts, illustrated here by the relationship between the ECJ and arbitral tribunals, the question arises whether this multiplication of courts and tribunals in international law may contribute in the end to a proliferation of disputes, which clearly would run counter to the rationale of any system of dispute settlement, namely to contain and definitively settle legal disputes in the interest of legal peace and legal certainty. In other words, the question is which devices exist to solve conflicts between jurisdictions.

First of all, it needs to be stressed that any appeal to hierarchy de lege ferenda between international judicial actors must remain hypothetical, if not purely fictitious. It is more of a thought experiment to deliberate on introducing a preliminary references procedure of sorts, with the ICJ being the addressee of questions for preliminary ruling put by other international courts and tribunals. ${ }^{75}$ Although seemingly appealing from the point of view of the unity and coherence of a matured international legal system, it is far from clear what could actually be gained by upgrad-

75 Nevertheless, such kind of mechanism, although cautiously worded, has been ventilated by Judge Schwebel, former president of the ICJ: 'in order to minimize such possibility as may occur of significant conflicting interpretations of international law, there might be virtue in enabling other international tribunals to request advisory opinions of the International Court of Justice on issues of international law that arise in cases before those tribunals that are of importance to the unity of international law', quoted from Martti Koskenniemi and Päivi Leino, 'Fragmentation of International Law? Postmodern Anxieties' (2002) 15 LJIL 553, 554. 
ing the ICJ to such an international super-court. As an idea that has no real backing in reality, it must be discarded as a legal glass bead game.

Second, a promise for resolution may be associated with the concept of a 'global community of courts', as most vociferously advocated by Slaughter: 'This community of courts is constituted above all by the self-awareness of the national and international judges who play a part. They are coming together in all sorts of ways. Literally, they meet much more frequently in a variety of settings, from seminars to training sessions and judicial organizations. Figuratively, they read and cite each other's opinions, which are now available in these various meetings, on the Internet, through clerks, and through the medium of international tribunals that draw on domestic case law and then cross-fertilize to other national courts. ${ }^{76}$ While the reality of international and national courts more frequently taking into account the work of their peers can hardly be disputed, ${ }^{77}$ observing such a community in statu nascendi is more descriptive than prescriptive. As a primarily sociological notion, its concrete legal impact appears unclear. Apart from that - as Slaughter explains - a community of courts does not necessarily entail more deference to the decisions of other courts, but may even breed more vigorous conflict. ${ }^{78}$ Hence, the actual relevance of this concept for the resolution of conflicts of jurisdictions remains uncertain and blurred.

Third, the seminal principles of res judicata and lis pendens may contain the potential for resolution. However, at least understood as formal concepts, they will often be inapplicable and thus incapable of actually resolving disputes. Both principles presuppose the 'same dispute', including the identity of the parties and subject matter. Coming back to the example of the potential conflict between the ECJ and the arbitral tribunal under UNLOS, it is far from clear that both judicial actors were concerned with the same dispute. The dispute before the ECJ involved the Commission and Ireland as parties, whereas before the arbitral tribunal the parties were Ireland and the UK. Moreover, the case before the ECJ was restricted to certain aspects of EC law, and was consequently only concerned with a fraction of the whole dispute at stake. ${ }^{79}$ One may also consider that a judgment rendered by the ECJ in the framework of

76 Anne-Marie Slaughter, 'A Global Community of Courts' (2003) 44 Harv ILJ 191, 192.

77 Taking an example from current international practice, one may refer to the ICJ heavily relying on the work of the ICTY in the Bosnian Genocide case (Application of the Convention on the Prevention and Punishment of the Crime of Genocide (Bosnia and Herzegovina $v$ Serbia and Montenegro) (Merits) 2007 <http://www.icj-cij.org/docket/files/91/13685.pdf> accessed 11 June 2007). For further examples, see Carl Baudenbacher, 'Judicial Globalization: New Developments or Old Wine in New Bottles?' (2003) 38 Tex ILJ 505.

78 Anne-Marie Slaughter, 'A Global Community of Courts' (2003) 44 Harv ILJ 191, 193.

79 Cf Cesare P.R. Romano, Case note on Case C-459/03 Commission v Ireland (2007) 101 AJIL 171, 178. 
infringement proceedings is purely declaratory of a violation of EC law, ${ }^{80}$ whereas the decision of an arbitral tribunal may have farther-reaching legal effects. ${ }^{81}$

Finally, one may refer to judicial comity as an avoidance technique for jurisdictional conflicts. Again, although firmly established in traditional international law, there is no prescriptive value to be gained from it, since courtoisie contains an appeal to a moral instead of a legal authority signal. Consequently, violating a concept of judicial comity may be perfectly legal as long as it has not been elevated to a norm of general international law. At the same time, the concept is not without merits for the present purposes, especially when combined with the principles of res judicata and lis pendens. More precisely, although at times formally inapplicable, res judicata and lis pendens may serve as yardsticks in assessing when judicial comity should be exercised. If two or more international courts are confronted with essentially the same dispute, judicial comity should be exercised. Certainly, it is not entirely clear how courts exercising judicial comity should proceed, and the concept of judicial comity is in need of further clarification. What is clear, however, is that judicial comity cannot work as a one-way street where one particular court regularly relies on comity to secure its maximum reach. Over and above that, a starting point may be gleaned from the words of Rosalyn Higgins who suggests as follows:

We judges are going to have to learn how to live in this new, complex world, and to regard it as an opportunity rather than a problem:

- We must read each other's judgments.

- We must have respect for each other's judicial work.

- We must try to preserve unity among us unless context really prevents this. ${ }^{82}$

This is as good as it gets in an international legal order characterised by in-built overlaps of judicial voices which should, however, aim at harmony instead of cacophony.

\footnotetext{
80 Koen Lenaerts and Dirk van Arts, Procedural Law of the European Union $\left(2^{\text {nd }}\right.$ edn Sweet \& Maxwell, London 2005) 5-063.

81 It is noteworthy in this context that in January 2007 the arbitral tribunal in MOX Plant, while suspending the obligation on the parties to regularly report on compliance with the provisional measures indicated, decided to remain seized of the dispute in spite of the ECJ's ruling and thus has not declined jurisdiction so far. See MOX Plant Case (Ireland $v$ UK) (Suspension of Periodic Reports by the Parties, Order No 5 of 22 January 2007).

82 Rosalyn Higgins, 'A Babel of Judicial Voices? Ruminations from the Bench' (2006) 55 ICLQ 791, 804.
} 